MATH DIDACTIC: JURNAL PENDIDIKAN MATEMATIKA

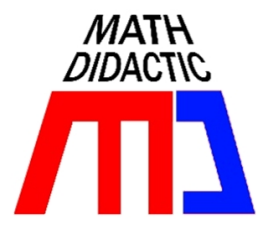

\title{
ETNOMATEMATIKA SEBAGAI SALAH SATU UPAYA PENGUATAN KEARIFAN LOKAL DALAM PEMBELAJARAN MATEMATIKA
}

\section{ETHNOMATEMATICS AS ONE OF THE EFFORT TO STRENGHTEN LOCAL WISDOM IN MATHEMATICS LEARNING}

Maria Isabella Chrissanti

Biro Administrasi Pembangunan Setda DIY

isabella.chrissanti@gmail.com

\begin{abstract}
Abstrak: Kajian ini bertujuan untuk membahas mengenai upaya penguatan kearifan lokal dalam pembelajaran, khususnya pembelajaran matematika, melalui pembelajaran berbasis budaya. Arus globalisasi perlahan telah mengikis nilai-nilai luhur budaya bangsa yang telah diwariskan oleh para leluhur sejak abad-abad sebelumnya. Nilai-nilai kearifan budaya lokal yang merupakan bagian dari identitas diri suatu bangsa seringkali terlupakan seiring kehidupan yang semakin modern. Apabila hal semacam ini terus-menerus dibiarkan terjadi, maka bukan tidak mungkin jika pada akhirnya bangsa ini akan kehilangan jati dirinya. Untuk itulah penguatan kearifan lokal menjadi suatu hal yang perlu diupayakan dengan sungguh-sungguh, salah satunya melalui pendidikan. Sekitar tahun 1985, D’Ambrosio memperkenalkan konsep pembelajaran berbasis budaya dalam konteks matematika yang kemudian dikenal dengan istilah etnomatematika. Secara umum, etnomatematika dapat dipandang sebagai suatu konsep pembelajaran matematika dalam kerangka budaya dan antropologi. Dalam etnomatematika, siswa bukan hanya diajak untuk mengembangkan kemampuan matematisnya melainkan juga mempertahankan budaya yang merupakan karakter asli bangsanya. Oleh sebab itu, etnomatematika dipandang relevan tidak hanya untuk mengembangkan kemampuan matematis siswa, namun juga memperkuat nilai-nilai kearifan lokal dalam diri siswa tersebut. Dalam kajian ini diperoleh kesimpulan bahwa pembelajaran matematika dengan etnomatematika memungkinkan untuk diterapkan yaitu dengan menyusun bahan ajar yang mengintegrasikan materi matematis dengan unsur-unsur budaya yang ada di tempat siswa belajar.
\end{abstract}

Kata kunci: kearifan lokal, pembelajaran matematika, etnomatematika

Abstract: This study is aimed to talk about the effort to strengthening the local wisdom in learning process, especially in mathematics learning through culture based learning. Globalization slowly threaten the nation's noble values inherited from the ancestors. Local wisdom values which is a part of a nation's identity, is often forgotten as the life becomes more and more modern. If this kind of situation keep happening continously, then this nation might be lost their identity. Hence, strengthening the local wisdom is something that needs to be seriously conducted, with education being one of the means. In 1985, D'Ambrosio introduce the concept of culture based learning in mathematical context known as ethnomathematics. In general, ethnomathematics can be saw as concepts of mathematics in a cultural and anthropological framework. In ethnomathematics, students were not only encouraged to improve their math skills, but also preserving culture which is the nation's indigenous character. Therefore, ethnomathematics is considered relevant in not only improving the students' math skills, but also strengthens their local wisdom values. The study conclude that ethnomathematics is possible to applicate in mathematics learning by arranging some teaching materials that integrate mathematics content and cultural element in student's environment.

Keywords: local wisdom, mathematics learning, ethnomathematics

Cara Sitasi: Chrissanti, M.I. (2018). Etnomatematika sebagai salah satu upaya penguatan kearifan lokal dalam pembelajaran matematika. Math Didactic: Jurnal Pendidikan Matematika, 4 Edisi Dies Natalis XXXII, 243-252. 
Indonesia merupakan suatu bangsa dengan latar belakang kebudayaan daerah yang beraneka ragam. Keberagaman tersebut menunjukkan betapa kayanya bangsa ini akan nilai-nilai luhur budaya bangsa yang telah diwariskan oleh para leluhur sejak abad-abad sebelumnya. Kekayaan ini akan tetap menjadi milik bangsa Indonesia apabila setiap generasi memiliki kesadaran untuk menjaga keberlangsungannya. Namun hal tersebut tentu bukan tanpa hambatan. Kenyataan bahwa arus globalisasi perlahan telah mengikis nilai-nilai budaya bangsa tak dapat dipungkiri. Nilai-nilai kearifan budaya lokal yang merupakan bagian dari identitas diri suatu bangsa seringkali terlupakan seiring kehidupan yang semakin modern. Apabila hal semacam ini terusmenerus dibiarkan terjadi, maka bukan tidak mungkin jika pada akhirnya bangsa ini akan kehilangan jati dirinya. Untuk itulah penguatan kearifan lokal menjadi suatu hal yang perlu diupayakan dengan sungguh-sungguh, salah satunya melalui pendidikan.

Ruyadi (2010, hal. 579) menyebutkan bahwa proses pendidikan tidak lebih dari proses transmisi kebudayaan. Lebih lanjut menurut Tilaar (Ruyadi, 2010, hal. 579), pendidikan merupakan proses pembudayaan. Oleh karenanyalah pendidikan tidak dapat dipisahkan dengan kebudayaan. Dengan kata lain, tidak ada kebudayaan tanpa pendidikan dan begitu pula praksis pendidikan selalu berada di dalam lingkup kebudayaan (Ruyadi, 2010, hal. 579). Mengacu pada hal tersebut, maka penguatan kearifan budaya lokal melalui pendidikan merupakan sesuatu yang sangat relevan.

Dunia pendidikan mengenal berbagai inovasi dalam kegiatan pembelajaran di sekolah. Salah satu pembelajaran yang dipandang berpotensi menguatkan kearifan lokal adalah pembelajaran berbasis budaya.
Pembelajaran berbasis budaya, menurut Pannen \& Sarjiyo (2005, hal. 87), merupakan strategi penciptaan lingkungan belajar dan perancangan pengalaman belajar yang mengintegrasikan budaya sebagai bagian dari proses pembelajaran. Pembelajaran tersebut dilandaskan pada pengakuan terhadap budaya sebagai bagian yang fundamental (mendasar dan penting) bagi pendidikan sebagai ekspresi dan komunikasi suatu gagasan dan perkembangan pengetahuan. Sedemikian sehingga pembelajaran berbasis budaya dapat membawa budaya lokal yang selama ini tidak selalu mendapat tempat dalam kurikulum sekolah, termasuk pada proses pembelajaran beragam mata pelajaran di sekolah (Pannen \& Sarjiyo, 2005, hal. 96).

Dari berbagai mata pelajaran di sekolah, matematika merupakan salah satu mata pelajaran yang wajib diajarkan. Hal ini diamanatkan dalam Undang-Undang RI No. 20 Tahun 2003 tentang Sistem Pendidikan Nasional yang menyebutkan bahwa mata pelajaran matematika merupakan salah satu mata pelajaran wajib bagi siswa pada jenjang pendidikan dasar dan menengah. Terkait hal tersebut maka pembelajaran berbasis budaya hendaknya dapat pula diaplikasikan dalam pembelajaran matematika di sekolah. Pertanyaan yang muncul kemudian adalah bagaimana cara mengaplikasikannya?

Seorang ilmuwan asal Brasil, Ubiratan D'Ambrosio, mengemukakan suatu konsep yang menghubungkan pembelajaran matematika dengan latar belakang budaya yang dimiliki dan dipahami oleh siswa. Konsep ini kemudian dikenal dengan istilah etnomatematika. Secara umum, etnomatematika dapat dipandang sebagai suatu konsep pembelajaran matematika dalam kerangka budaya dan antropologi. Dalam etnomatematika, siswa bukan hanya diajak 
untuk mengembangkan kemampuan matematisnya melainkan juga mempertahankan budaya yang merupakan karakter asli bangsanya. Oleh sebab itu, etnomatematika dipandang relevan tidak hanya untuk mengembangkan kemampuan matematis siswa, namun juga memperkuat nilai-nilai kearifan lokal dalam diri siswa tersebut. Lebih lanjut mengenai upaya penguatan kearifan lokal dalam pembelajaran, khususnya pembelajaran matematika melalui etnomatematika, akan dibahas dalam kajian ini.

\section{Pembahasan}

\section{Kearifan Lokal}

Kearifan lokal (local wisdom) tersusun atas kata kearifan (wisdom) dan lokal (local). Istilah kearifan (wisdom) mengandung makna kebijaksanaan, sedangkan lokal (local) berarti setempat. Mengacu pada hal tersebut maka secara umum kearifan lokal dapat dimaknai sebagai gagasan-gagasan setempat yang bersifat bijaksana, memiliki nilai yang baik, yang telah tertanam dan diikuti oleh masyarakat setempat. Hal ini sejalan dengan pendapat Sudarsana (2017, hal. 218) yang menyatakan bahwa kearifan lokal merupakan kebijakan manusia dalam mengembangkan keunggulan lokal yang bersandar pada filosofi nilai-nilai, etika, cara-cara dan perilaku yang melembaga secara tradisional. Lebih jauh, Sartini (2004, hal. 113) menggambarkan kearifan lokal sebagai suatu gagasan konseptual yang hidup dalam masyarakat, tumbuh dan berkembang secara terus menerus dalam kesadaran masyarakat, berfungsi dalam mengatur kehidupan masyarakat yang sifatnya berkaitan dengan kehidupan yang sakral sampai yang profan.
Kearifan lokal juga kerap dikaitkan dengan aktivitas-aktivitas tertentu yang terbangun di kalangan masyarakat setempat sehubungan dengan upaya-upaya pemenuhan kebutuhan hidup mereka. Sebagaimana dipaparkan oleh Fajarini (2014, hal. 123), kearifan lokal adalah pandangan hidup dan ilmu pengetahuan serta berbagai strategi kehidupan yang berwujud aktivitas yang dilakukan oleh masyarakat lokal dalam menjawab berbagai masalah dalam pemenuhan kebutuhan mereka. Dengan demikian, kearifan lokal yang berkembang di masyarakat wilayah tertentu dapat berbeda dengan di wilayah lain tergantung pada ketersediaan bahan maupun sarana pemenuhan kebutuhan masyarakat di wilayah tersebut. Hal ini menimbulkan suatu budaya tersendiri dalam masyarakat itu yang belum tentu dimiliki oleh masyarakat di wilayah lain.

Pusaran arus globalisasi saat ini menjadikan kearifan lokal sebagai suatu hal yang harus diupayakan keberlangsungannya dengan sungguh-sungguh. Hal ini karena globalisasi membawa dampak negatif yang cukup serius bagi bangsa Indonesia. Wuryandani (2010, hal. 6) menyebutkan beberapa dampak negatif globalisasi, diantaranya kecenderungan masyarakat kita khususnya anak muda yang lupa akan identitas diri sebagai bangsa Indonesia, karena gaya hidupnya cenderung meniru budaya barat yang oleh masyarakat dunia dianggap sebagai kiblat serta munculnya sikap individualisme yang menimbulkan ketidakpedulian antarperilaku sesama warga. Individualisme, mengakibatkan orang cenderung tidak peduli dengan kehidupan bangsa. Hal semacam ini tentu merupakan ancaman bagi kehidupan berbangsa. Dalam situasi semacam ini, penguatan nilai kearifan lokal sangat diperlukan agar bangsa ini tidak kehilangan 
jati dirinya. Menurut Sudarma dalam Sudarsana (2017, hal. 218), konsep kearifan lokal dalam konteks kehidupan dan relasi sosial di tengah komunitas yang majemuk memiliki kekuatan (power) dalam menciptakan suasana sosial yang kondusif. Selain itu, kearifan lokal juga dipandang memiliki peran dalam pendidikan karakter bangsa (Fajarini, 2014, hal. 124). Oleh karena itu, sebagaimana disampaikan oleh Sartini (2004, hal. 112), kearifan lokal yang tidak lain adalah produk budaya masa lalu patut secara terus-menerus dijadikan pegangan hidup.

\section{Pembelajaran Matematika}

Menurut UU No. 20 Tahun 2003 tentang Sistem Pendidikan Nasional, pembelajaran dimaknai sebagai proses interaksi peserta didik dengan pendidik dan sumber belajar pada suatu lingkungan belajar. Sementara itu, UU No. 20 Tahun 2003 tentang Sistem Pendidikan Nasional juga menyebutkan bahwa matematika merupakan salah satu mata pelajaran yang wajib untuk diajarkan dalam pembelajaran pada jenjang pendidikan dasar dan menengah. Pembelajaran matematika hendaknya dimulai dengan pengenalan masalah yang sesuai dengan situasi (contextual problem). Dengan mengajukan masalah kontekstual, siswa secara bertahap dibimbing untuk menguasai konsep matematika (Supinah dalam Ayuningtyas \& Setiana, 2018, hal. 363)

Terkait dengan tujuan pembelajaran matematika di sekolah, Peraturan Menteri Pendidikan Nasional Nomor 22 Tahun 2006 menyebutkan bahwa pembelajaran matematika pada jenjang pendidikan dasar dan menengah bertujuan untuk mempersiapkan siswa agar sanggup menghadapi perubahan keadaan di dalam kehidupan dan di dunia yang selalu berkembang, melalui latihan bertindak atas dasar pemikiran secara logis, rasional, kritis, cermat, jujur, efisien dan efektif. Sedangkan menurut Suherman, dkk (2003, hal. 58), tujuan umum pembelajaran matematika antara lain memberikan penekanan pada penataan nalar dan pembentukan sikap siswa, yaitu memberikan penekanan pada keterampilan dalam penerapan matematika, baik dalam kehidupan sehari-hari maupun dalam mempelajari ilmu pengetahuan lainnya. Lebih lanjut, Suherman, dkk (2003, hal. 62) menyatakan bahwa yang dimaksud dengan belajar aktif dalam matematika adalah siswa dibawa ke dalam suatu kegiatan mengamati, menebak, berbuat, mencoba, mampu menjawab pertanyaan mengapa, dan kalau mungkin berdebat. Prinsip belajar aktif inilah yang kemudian diharapkan mampu menumbuhkan sasaran pembelajaran matematika yang kreatif dan kritis. Melalui prinsip belajar secara aktif, pembelajaran matematika di sekolah diharapkan dapat meraih keberhasilan.

\section{Etnomatematika}

Perlu disadari bahwa keberhasilan pembelajaran matematika di sekolah tidak terlepas dari profesionalisme guru yang mengampu mata pelajaran tersebut. Ayuningtyas \& Setiana (2018, hal. 363) berpendapat bahwa agar pembelajaran matematika dapat dilaksanakan secara profesional, seorang guru dituntut untuk dapat memahami dan memiliki keterampilan yang memadai dalam mengembangkan berbagai model, pendekatan, strategi, metode, teknik, dan taktik maupun desain pembelajaran yang efektif, kreatif dan menyenangkan. Seorang guru juga hendaknya memahami model, pendekatan, atau strategi pembelajaran seperti apa yang tepat diterapkan pada suatu keadaan tertentu. Dalam situasi yang berkembang saat 
ini, sebagaimana telah diuraikan sebelumnya, membelajarkan matematika dengan nuansa budaya dapat menjadi alternatif inovasi pembelajaran bagi guru. Di satu sisi, pembelajaran semacam ini dapat menguatkan kecintaan siswa akan budaya-budaya lokal yang menjadi bagian dari jati dirinya. Di sisi lain, pembelajaran matematika dalam nuansa budaya dirasa dapat menciptakan lingkungan belajar yang menyenangkan dimana siswa dan guru dapat berpartisipasi aktif berdasarkan budaya yang sudah mereka kenal, sehingga dapat diperoleh hasil belajar yang optimal. Siswa merasa senang dan diakui keberadaan serta perbedaannya, karena pengetahuan dan pengalaman budaya yang sangat kaya yang mereka miliki dapat diakui dalam proses pembelajaran (Pannen \& Sarjiyo, 2005, hal. 84).

Pendapat tersebut sejalan dengan NCTM yang menyebutkan bahwa siswa harus mempelajari matematika melalui pemahaman dan aktif membangun pengetahuan baru dari pengalaman dan pengetahuan yang telah dimiliki sebelumnya. Untuk itu, NCTM merumuskan enam prinsip pembelajaran matematika sekolah, yaitu: 1.) Prinsip kesetaraan, 2.) prinsip kurikulum, 3.) prinsip pengajaran, 4.) prinsip pembelajaran, 5.) prinsip penilaian, dan 6.) prinsip teknologi. (NCTM, 2000, hal. 11). Pengalaman dan pengetahuan yang dimiliki sebelumnya oleh siswa tak terlepas dari pengalaman terkait budaya-budaya yang berkembang di lingkungan tempat mereka belajar. Karena meski matematika bukan berasal dari Indonesia, namun para siswa mempelajarinya dalam komunitas budaya Indonesia. Sehingga, menurut Pannen \& Sardjiyo (2005, hal. 86), walaupun matematika berasal dari Yunani namun penerapan rumus-rumus dan torema matematika serta pola penalaran matematika yang dipelajari di sekolah di Indonesia ada dalam lingkungan budaya Indonesia.

Konsep mengenai pembelajaran matematika dalam kerangka budaya digagas oleh ilmuwan asal Brasil, Ubiratan D'Ambrosio. D'Ambrosio mengamati bahwa telah banyak penelitian mengenai etnoastronomi, etnobotani, etnokimia, dan lain sebagainya namun tidak demikian dengan etnomatematika. Hal ini diduga karena sifat matematika yang dianggap universal dan tidak terkait dengan budaya tertentu. Akan tetapi hal ini nampaknya bertentangan dengan hasil temuan para antropologis melalui penelitiannya. Hasil penelitian para antropologis menunjukkan bahwa dalam kelompok-kelompok masyarakat telah terdapat aktivitas bersifat matematis seperti menghitung, mengurutkan, mengukur, maupun menimbang yang berbeda dengan aktivitas serupa yang diajarkan secara umum di sekolah. Dari sini nampak bahwa aktivitas matematis tidak hanya muncul sebagai produk kegiatan belajar mengajar di sekolah, namun juga timbul sebagai produk budaya dalam suatu kelompok masyarakat.

D'Ambrosio (1985, hal. 44) meyakini bahwa membuat konsep yang dapat menjadi jembatan penghubung antara para antopologis dan ahli sejarah budaya dengan para matematikawan merupakan langkah penting untuk mengenali bahwa perbedaan cara berpikir suatu masyarakat dapat mengarah pada bentuk matematika yang berbeda pula. Sehingga perkembangan matematika yang merupakan ilmu dasar tersebut dapat berbedabeda di tiap wilayah karena pengaruh budaya di wilayah tersebut. Yang artinya, setiap kebudayaan mengembangkan matematikanya sendiri. Konsep inilah yang kemudian dikenal dengan etnomatematika. 
Ditinjau dari kata penyusunnya, etnomatematika atau ethnomathematics berasal dari kata ethno, mathema, dan tics. D’Ambrosio dalam Rosa \& Orey (2007, hal. 11) menjelaskan bahwa:

"The prefix ethno is today accepted as a very broad term that refers to the social-cultural context, and therefore includes language, jargon, and codes of behavior, myths, and symbols The derivation of mathema is difficult, but tends to mean to explain, to know, to understand, and to do activities such as ciphering, measuring, classifying, ordering, infetting, and modeling The suffix tics is derived from techne, and has the same root as art and technique. Dapat dipahami kemudian bahwa kata ethno mengacu pada sosial konteks budaya yang terdiri dari bahasa, jargon, kode perilaku, mitos dan simbol. Sedangkan mathema diartikan sebagai aktivitas menjelaskan, mengetahui, memahami kegiatan seperti menyandikan, mengukur, mengelompokkan, menyimpulkan, dan pemodelan. Kemudian tics berarti teknik atau cara. Dengan demikian, etnomatematika mengacu pada teknik atau cara-cara yang digunakan oleh anggota kelompok dengan lingkungan tradisi budaya tertentu (meliputi bahasa, jargon, kode perilaku, mitos, maupun simbol) dalam melakukan kegiatan menyandikan, mengukur, mengelompokkan, menyimpulkan, dan pemodelan.

Sejalan dengan hal tersebut, Barton (1994, hal. 196) menyebutkan bahwa "Ethnomathematics is a field of study which examines the way people from other cultures understand, articulate and use concepts and practices which are from their culture and which the researcher describes as mathematical'. Hal ini berarti etnomatematika merupakan suatu bidang ilmu yang mengkaji cara sekelompok orang dengan latar belakang budaya tertentu dalam memahami, mengekspresikan, serta menggunakan konsepkonsep dan praktek-praktek kebudayaannya yang oleh peneliti dikategorikan sebagai aktivitas matematis. Sehingga secara umum, etnomatematika dapat dipandang sebagai konsep matematika dalam kerangka budaya dan antropologi. Dengan kata lain, etnomatematika merupakan irisan antara matematika, antropologi budaya, dan pemodelan matematika (Rosa \& Orey, 2007, hal. 11).

Menerapkan etnomatematika dalam proses pembelajaran matematika di sekolah bukan berarti mengajak siswa untuk meninggalkan pembelajaran yang bernuansa modern untuk kemudian kembali pada jaman dahulu atau menjadi primitif. Fokus dari pembelajaran dengan etnomatematika adalah mengupayakan agar karakter asli budaya yang dimiliki siswa dapat bertahan di masa sekarang ini. Sehingga melalui pembelajaran tersebut dapat terbangun karakter siswa yang tidak hanya memahami budayanya namun juga mampu menerapkannya dalam kehidupan sehari-hari. Menurut Gerdes (1994, hal. 20), terdapat beberapa karakter dari pembelajaran dengan etnomatematika antara lain :

i) Menggunakan konsep matematika secara luas, khususnya menghitung, menemukan, mengukur, mendesain, bermain dan menjelaskan;

ii) Menekankan dan menganalisa pengaruh faktor sosial-budaya pada proses pengajaran, pembelajaran, dan pengembangan matematika;

iii) Memaknai matematika sebagai suatu produk budaya, dimana setiap budaya mengembangkan matematikanya sendiri; 
iv) Memungkinkan siswa untuk merefleksikan latar belakang budaya tempat mereka hidup, serta mendorong mereka untuk membangun dan menerapkan matematika dengan cara yang bebas sesuai dengan realitas tersebut.

Menurut Goldberg dalam Supriadi, dkk (2016, hal. 5-6), pembelajaran berbasis budaya dengan etnomatematika dapat dilakukan melalui tiga cara yaitu belajar tentang budaya, belajar dengan budaya, dan belajar melalui budaya. Sedangkan kajian etnomatematika dalam pembelajaran matematika menurut Ekowati, dkk (2017, hal. 718) mencakup segala bidang: arsitektur, tenun, jahit, pertanian, tarian tradisional, kain batik, hubungan kekerabatan, ornamen, dan spiritual serta praktik keagamaan. Dengan demikian, para guru dapat menggunakan aktivitas masyarakat maupun unsur-unsur budaya yang dimiliki oleh lingkungan siswa untuk kemudian menggali bersama siswa konsepkonsep matematis apa yang ada dalam aktivitas maupun unsur budaya tersebut. Misalnya saja guru dapat membawa siswa ke bangunan-bangunan peninggalan budaya setempat dan kemudian mempelajari unsurunsur matematis (contonya konsep bangun ruang, bangun datar, luas permukaan, dan lainlain) yang ada pada bangunan tersebut. Melalui kegiatan ini, siswa dapat makin mengenal kekayaan warisan budaya leluhurnya sekaligus memperoleh wawasan tentang konsep matematika. Selain itu, guru dapat pula membelajarkan matematika dengan menggunakan bahasa daerah yang digunakan sehari-hari oleh siswa. Dengan membelajarkan matematika melalui hal-hal yang dekat dengan keseharian siswa, akan membuat siswa tersebut merasa lebih nyaman dan percaya diri ketika membahas konsep-konsep matematika.
Pembelajaran matematika dengan menggunakan etnomatematika telah lebih dulu diterapkan oleh negara-negara tetangga seperti Jepang, Korea, dan Cina. Negara-negara tersebut telah lama menggunakan budayanya dalam pembelajaran matematika dan merasakan manfaat positif dari kegiatan tersebut. Menurut Kurumeh dalam Supriadi, dkk (2016, hal. 2), penggunaan etnomatematika dalam pembelajaran matematika menjadi salah satu faktor penyebab keberhasilan negara-negara tersebut dalam pembelajaran matematika. Penerapan dan manfaat etnomatematika juga dirasakan oleh Bonner (Ayuningtyas \& Setiana, 2018, hal. 365), yang melakukan kegiatan pembelajaran berbasis etnomatematika dengan subjek para calon guru. Pembelajaran tersebut dilakukan dengan membangun pengalaman bermakna yang berfokus pada budaya, baik di dalam maupun di luar kelas. Hasil yang diperoleh menunjukkan bahwa kegiatan tersebut telah meningkatkan dan memperdalam pemahaman calon guru dalam pengajaran matematika dengan berbagai macam budaya. Selain itu, kegiatan seminar yang dilakukan Massarwe, Verner, \& Bshouty pada tahun 2012 menyimpulkan bahwa, pemahaman tentang geometri para siswa/peserta seminar meningkat dan mereka paham terhadap pentingnya aktivitas pembelajaran etnomatematika yang berhubungan dengan siswa dan budaya yang lain (Ayuningtyas \& Setiana, 2018, hal. 365).

Penelitian mengenai manfaat penerapan etnomatematika tidak hanya dilakukan di luar negeri, namun juga dilakukan di Indonesia. Pada tahun 2012 Supriadi mengamati sebanyak 80 orang mahasiswa UPI Kampus Serang selama satu semester dan memperoleh data bahwa $80 \%$ dari mahasiswa tersebut tidak memahami budaya yang ada saat 
pembelajaran matematika berlangsung. Permasalahan tersebut diduga disebabkan kurangnya penyajian budaya sebagai tema pada saat pembelajaran matematika di SD, SMP, SMA, maupun perguruan tinggi (Supriadi dkk, 2016, hal. 2-3). Kemudian pada tahun 2016, Supriadi, dkk memaparkan hasil penelitiannya yang mengintegrasikani pembelajaran matematika dengan basis budaya Banten pada tahap pendirian SD Laboratorium UPI Kampus Serang. Dalam penelitian ini, disusun suatu bahan ajar yang menggunakan aspek budaya Banten sebagai salah satu instrumen penelitian. Penyusunan bahan ajar tersebut oleh Supriadi, dkk dirasa sesuai dengan amanat kurikulum pendidikan dasar yang mengedepankan aspek budaya dalam memelihara dan mengembangkan kearifan lokal dalam pembelajaran, salah satunya pada mata pelajaran matematika. Data yang diperoleh dari penelitian ini menunjukkan bahwa para siswa yang menjadi subjek penelitian menyatakan senang mempelajari matematika dengan menggunakan bahasa daerah, baik itu bahasa Sunda maupun bahasa Jawa. Sedangkan dari aspek kuantitatif, diperoleh hasil bahwa pembelajaran matematika dengan berbasis budaya Banten yang dilakukan oleh Supriadi, dkk memiliki keunggulan yang signifikan baik dari ketercapaian KKM maupun rerata kelas sehari-hari. (Supriadi dkk, 2016, hal. 13-16).

Tidak hanya di wilayah Jawa Barat, upaya penerapan etnomatematika dalam pembelajaran matematika juga dilakukan di Jawa Timur oleh Ekowati, dkk. Ekowati, dkk menerapkan etnomatematika melalui pembelajaran bilangan pada siswa sekolah dasar dengan memanfaatkan media berupa batik madura, tari khas trenggal, dan tari khas madura. Media belajar yang digunakan berupa kartu bilangan yang memuat gambar berkearifan lokal di satu sisi dan bilanganbilangan di sisi yang lainnya. Bagian gambar berkearifan lokal berfungsi sebagai pengenal sekaligus memperdalam pengetahuan mengenai budaya tersebut. Sedangkan bagian sisi bilangan berfungsi untuk menjelaskan konsep dan selanjutnya memperdalam pemahaman siswa terhadap materi bilangan. (Ekowati, dkk, 2017, hal. 719).

Penyusunan bahan ajar berbasis etnomatematika juga dilakukan di Daerah Istimewa Yogyakarta, salah satunya oleh Ayuningtyas\&Setiana. Menyisipkan unsur budaya dalam rencana pembelajaran, diyakini dapat menanamkan karakter berbudaya luhur pada siswa. Kedua peneliti ini menyusun bahan ajar dengan memanfaatkan Kraton Yogyakarta sebagai salah satu situs budaya di DIY. Dipilihnya Kraton Yogyakarta pada penyusunan bahan ajar ini dikarenakan sebagai salah satu situs budaya, Kraton Yogyakarta memiliki banyak unsur budaya yang dapat dikaji dan dikaitkan dalam pembelajaran. Unsur-unsur tersebut antara lain seni arsitektur yang tinggi, benda-benda kuno bersejarah, pusaka, gamelan, dokumen sastra Jawa, dan lain sebagainya. Bahan ajar etnomatematika dengan tema Kraton Yogyakarta yang disusun oleh Ayuningtyas \& Setiana berisi ringkasan materi dan latihan soal mengenai bangun datar dan bangun ruang yang berasal dari ornamenornamen, benda-benda, maupun bangunanbangunan yang terdapat pada Kraton Yogyakarta. Melalui bahan ajar tersebut, siswa dapat belajar mengenal unsur-unsur budaya di Kraton Yogyakarta sekaligus mempelajari materi matematika khusunya bangun ruang sisi datar. (Ayuningtyas \& Setiana, 2018, hal. 365368).

Contoh-contoh penerapan maupun penyusunan bahan ajar etnomatematika yang telah dijabarkan di atas menunjukkan bahwa 
menerapkan pembelajaran matematika dengan basis budaya bukanlah hal yang tidak mungkin dilakukan. Dalam hal ini para guru dituntut untuk mengembangkan kreatifitas dalam menemukan unsur-unsur budaya yang dapat di bawa ke dalam konteks pembelajaran matematika siswa. Sehingga pelajaran matematika tidak lagi diajarkan sebagai konsep-konsep abstrak, namun juga sebagai konsep yang dekat dengan keseharian siswa dan tumbuh sebagai produk budaya di mana siswa belajar. Dengan demikian siswa akan memiliki pengetahuan matematis yang baik sekaligus pemahaman dan kecintaan terhadap budaya-budaya yang dimilikinya.

\section{Simpulan dan Saran}

\section{Simpulan}

1. Globalisasi membawa dampak negatif yang cukup serius bagi generasi muda berupa kecenderungan menjadikan budaya barat sebagai kiblat gaya hidup sehingga lupa akan jati diri sebagai bangsa Indonesia.

2. Penguatan nilai-nilai kearifan lokal dapat dilakukan sejak dini melalui kegiatan pembelajaran di sekolah, salah satunya pada pembelajaran matematika melalui etnomatematika.

3. Menerapkan pembelajaran matematika dengan etnomatematika dapat dilakukan dengan menyusun bahan ajar yang mengintegrasikan materi matematis dengan unsur-unsur budaya tempat siswa belajar.

\section{Saran}

1. Pembelajaran matematika berbasis budaya hendaknya mulai dikembangkan lebih jauh dan diterapkan dalam kegiatan belajar dan mengajar di sekolah.

2. Para guru hendaknya mulai mengembangkan bahan ajar yang memuat unsur-unsur budaya dan mengintegrasikannya dengan materi pembelajaran matematika.

\section{Daftar Pustaka}

Ayuningtyas, A. D., \& Setiana, D. S. (2018). Bahan ajar matematika berbasis etnomatematika Kraton Yogyakarta. Prosiding, Seminar Nasional Matematika dan Pendidikan Matematika yang diselenggarakan oleh UMPWR, tanggal $12 \mathrm{Mei}$ 2018. Purworejo: Universitas Muhammadiyah Purworejo.

Barton. (1994). Ethnomathematics:Exploring Cultural Diversity in Mathematics. Disertasi, tidak dipublikasikan. University of Auckland.

D'Ambrosio, U. (1985). Ethnomathematics and its place in the history and pedagogy of mathematics. For the Learning of Mathematics, 5(1), 44-48.

Ekowati, D. W., Kusumaningtyas, D. I., \& Sulistyani, N. (2017). Ethnomathematica dalam Pembelajaran Matematika (Pembelajaran Bilangan dengan Media Batik Madura, Tari Khas Trenggal dan Tari Khas Madura). Jurnal Pemikiran dan Pengembangan Sekolah Dasar (JP2SD), 5(2), 716-721.

Fajarini, U. (2014). Peranan kearifan lokal dalam pendidikan karakter. SOSIO- 
DIDAKTIKA: Social Science Education Journal, 1(2), 123-130.

Gerdes, P. (1994). Reflections on ethnomathematics. For the Learning of Mathematics, 14(2), 19-22.

National Council of Teacher of Mathematics. (2000). Principles and Standard for School Mathematics. Reston, V. A.: NCTM.

Orey, D., \& Rosa, M. (2007). Cultural assertions and challenges towards pedagogical action of an ethnomathematics program. For the Learning of Mathematics, 27(1), 10-16.

Republik Indonesia. (2003). Undang-Undang RI Nomor 20, Tahun 2003, tentang Sistem Pendidikan Nasional

Ruyadi, Y. (2010). Model pendidikan karakter berbasis kearifan budaya lokal (penelitian terhadap masyarakat adat kampung benda kerep Cirebon provinsi jawa barat untuk pengembangan pendidikan karakter di sekolah). Proceedings of The 4th International Conference on Teacher Education (577595) diselenggarakan oleh UPI, tanggal 8-10 November 2010. Bandung: Universitas Pendidikan Indonesia.

Sardjiyo \& Pannen, P. (2005). Pembelajaran berbasis budaya: model inovasi pembelajaran dan implementasi kurikulum berbasis kompetensi. Jurnal Pendidikan, 6(2), 83-98.

Sartini, S. (2004). Menggali Kearifan Lokal Nusantara: Sebuah Kajian
Filsafati. Jurnal Filsafat, 14(2), 111120.

Sudarsana, I. K. (2017, October). Pengembangan pendidikan berbasis kearifan lokal untuk mewujudkan toleransi antar umat beragama. Prosiding, Seminar Nasional Filsafatyang diselenggarakan oleh Fakultas Brahma Widya IHDN, tanggal 17 Maret 2017. Denpasar: Institut Hindu Dharma Negeri Denpasar.

Supriadi, S., Arisetyawan, A., \& Tiurlina, T. (2016). Mengintegrasikan Pembelajaran Matematika Berbasis Budaya Banten Pada Pendirian SD Laboratorium UPI Kampus Serang. Mimbar Sekolah Dasar, 3(1), 1-18.

Wuryandani, W. (2010). Integrasi nilai-nilai kearifan lokal dalam pembelajaran untuk menanamkan nasionalisme di sekolah dasar. Prosiding, Seminar Nasional Lembaga Penelitian yang diselenggarakan oleh UNY. Yogyakarta: Universitas Negeri Yogyakarta. 